\title{
Nutrient and food intakes differ among Latina subgroups during pregnancy
}

\author{
Amber Hromi-Fiedler ${ }^{1,2, *}$, Angela Bermúdez-Millán ${ }^{2,3}$, Sofia Segura-Pérez ${ }^{2,3}$ and \\ Rafael Pérez-Escamilla ${ }^{1,2}$ \\ 'Office of Community Health, Yale School of Public Health, Yale University, 135 College Street, Suite 200, \\ New Haven, CT 06510, USA: ${ }^{2}$ Connecticut Center for Eliminating Health Disparities among Latinos, Department \\ of Nutritional Sciences, University of Connecticut, Storrs, CT, USA: ${ }^{3}$ Hispanic Health Council, Hartford, CT, USA
}

Submitted 19 November 2010: Accepted 1 April 2011: First published online 23 June 2011

\begin{abstract}
Objective: To document nutrient and food group serving intakes from food sources among Latina subgroups living in the same geographical area.

Design: A cross-sectional study. Nutrient and food group serving intakes were assessed by means of a $24 \mathrm{~h}$ recall administered immediately after a prenatal survey. Setting: Hartford, CT, USA.

Subjects: A total of 233 low-income pregnant Latinas. For analyses, Latinas were classified into two groups on the basis of self-reported ethnic identity: Puerto Ricans and non-Puerto Rican Latinas.

Results: Puerto Rican Latinas were more likely than non-Puerto Rican Latinas to be more acculturated and to consume foods (i.e. processed meat, cheese, soft drinks) and higher levels of nutrients (i.e. fat, SFA, MUFA, trans fatty acids) that have been implicated in the development of chronic diseases. By contrast, non-Puerto Rican Latinas were more likely to consume foods (i.e. fruits, dark green/yellow vegetables, tomatoes, non-starchy vegetables) and higher levels of nutrients (i.e. fibre, vegetable protein, folate, $\beta$-carotene) that promote health when compared with Puerto Rican Latinas.

Conclusions: Findings suggest that acculturation may play a role in dietary intake. Clinicians and dietitians need to be aware of these differences to encourage healthy eating patterns among more acculturated pregnant Latina clients.
\end{abstract}

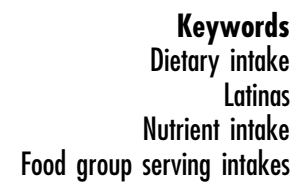

Counselling women about healthy dietary intake patterns during pregnancy requires knowledge of the overarching dietary recommendations and knowledge of the nutrient and food intakes of pregnant women. Programmes that provide prenatal nutritional education are more effective at counselling their clients if they have an understanding of the dietary patterns, including the types and amounts of food and nutrients consumed, of the population they are addressing. Prenatal programmes that predominantly serve Latinas may serve several subpopulations, including women from different Central and South American countries, Mexico and Puerto Rico. Yet, research on prenatal dietary patterns among different Latina subgroups is limited. Thus, little is known about the dietary patterns of diverse Latina subgroups and even less is known about differences in nutrient and food group intake patterns between Latina subgroups, especially between those living in the same geographical area.

Despite the strong links between dietary intake and birth outcomes ${ }^{(1-11)}$ and the differences in birth outcomes between Latina subgroups (Puerto Ricans have the highest rates of low birth weight and very premature births among the Latina subgroups) ${ }^{(12-15)}$, few studies have documented nutrient and food group serving intake patterns among pregnant Latinas ${ }^{(16-23)}$. Most of these studies have been conducted among women of Mexican descent. Diets of pregnant women of Mexican descent are influenced by acculturation ${ }^{(16,24)}$. Mexico-born women consume significantly more fibre, vitamins A, C and E, folate, $\mathrm{Ca}$ and $\mathrm{Zn}$, as well as more servings of fruit, grains and dairy products, per day compared with US-born women of Mexican descent ${ }^{(16)}$. However, the longer that Mexican-born women live in the USA, the less likely they are to consume optimal amounts of nutrients ${ }^{(16)}$. Mexican women who grow up in the USA and have lower social support are more likely to have poorer dietary quality compared with those who grow up in Mexico ${ }^{(24)}$. Findings from these studies suggest that traditional dietary patterns provide more nutrients and nutrient-rich foods compared with a US-based diet and that traditional patterns become modified to US patterns the longer an immigrant lives in the USA. 
To our knowledge, only one study has documented differences in nutrient intakes among pregnant Latina subgroups. That cross-sectional study conducted in New York over 30 years ago with a multiethnic sample of low-income pregnant women was limited by the comparison of intakes of only nine nutrients (i.e. energy, protein, $\mathrm{Ca}, \mathrm{Fe}$, vitamins $\mathrm{A}$ and $\mathrm{C}$, thiamin, riboflavin and niacin) ${ }^{(18)}$

Results from separate, individual studies conducted among either Mexican-American ${ }^{(16,17,19,21,22)}$ or Puerto Rican women ${ }^{(20,23)}$ suggest that dietary patterns may be different among Latina subgroups; yet, direct comparisons among different Latina subgroups could not be made because those studies: (i) were conducted in different geographical areas; (ii) did not use the same inclusion criteria; (iii) were conducted at different time points, with many being outdated (i.e. conducted in or before the 1990s); and (iv) reported on only selected nutrients and/or food groups. The only study that compared nutrient intakes among Latina subgroups ${ }^{(18)}$ is limited in scope as it: (i) included only high-risk obstetric patients; (ii) reported nutrient intake differences for only nine nutrients with no information regarding daily food group serving consumption; and (iii) was conducted more than three decades ago. Therefore, the primary goal of the present study was to compare current nutrient and food group serving intakes from food sources between Latina subgroups living in the same geographical area.

\section{Methods}

Before beginning the present study, Institutional Review Board approvals were obtained from all collaborating institutions, which included the University of Connecticut, Hartford Hospital, the Hispanic Health Council and Saint Francis Hospital and Medical Center. Participants also provided written informed consent before administration of the survey.

\section{Study population}

The present study was conducted with a convenience sample of 241 low-income pregnant Latinas living within Hartford county in Connecticut. Women were recruited from local programmes and agencies including: the Special Supplemental Nutrition Program for Women, Infants, and Children (WIC; $51 \cdot 1 \%$ ); maternal and infant service programmes $(15 \cdot 0 \%)$; other programmes and activities from a local community agency (13.3\%); phone and street outreach (8.9\%); family/friend referrals (4.3\%); local stores and restaurants (3.8\%); an area hospital (1.7\%); local community health centre or health service organization $(0 \cdot 8 \%)$; and elementary schools $(0 \cdot 8 \%)$. Recruitment occurred across two time periods: from July 2004 to December 2004 ( $n$ 103) and from September 2005 to December 2006 ( $n$ 138).
Women were recruited if they: (i) identified themselves as Latina; (ii) were pregnant; (iii) lived in the Hartford area; (iv) were $\geq 18$ years of age; and (v) were participating in WIC or were eligible for WIC. Women recruited from September 2005 to December 2006 had to meet additional inclusion criteria. They were included if they met the above inclusion criteria and were also between 4 and 8 months pregnant, planning to deliver at one of the two city hospitals and were not homeless.

Bilingual/bicultural interviewers administered a survey at study enrolment. Ethnicity was assessed by having participants classify themselves into the following categories: (i) Puerto Rican; (ii) Hispanic or Latina; (iii) Puerto Rican American; (iv) American; or (v) other. Participants who identified themselves as 'Hispanic/Latina' or 'other' were asked to specify their Latina sub-ethnicity. If ethnicity was not reported, place of birth was used to assign it ( $n$ 18). Since approximately $70 \%$ of the study sample was of Puerto Rican descent, ethnicity was recoded into Puerto Ricans and non-Puerto Rican Latinas. Level of acculturation was assessed using proxy measures including language preference (English, English/Spanish, Spanish), type of birthplace (US born, non-US born - urban, non-US born rural) and length of time of living in the USA (below the median, at the median or above the median).

\section{Dietary intake assessment}

Dietary intake was assessed using a $24 \mathrm{~h}$ recall administered immediately after the baseline survey, with $13 \cdot 3 \%$ of the $24 \mathrm{~h}$ recalls reflecting a weekend day. Interviewers followed the standardized multiple pass methodology ${ }^{(25)}$. Culturally appropriate food models, measuring spoons and cups, bowls, plates and utensils were used to help participants report serving sizes. Participants who had difficulty in estimating portion sizes with our measuring instruments were given an opportunity to use their own household items to arrive at the estimate. For example, participants had the option of filling their own mug or cup used for drinking beverages with the amount of water corresponding to the amount consumed. The interviewer then measured the amount of water in the cup using the study's measuring instruments. As a quality control measure, specific food items and restaurant foods were also purchased, measured and/or weighed. For example, if a participant consumed a piece of beef flank from a local restaurant, the restaurant was contacted and asked to provide a standard-sized piece of beef flank that was usually provided to customers. After it was purchased, it was measured and weighed. This measurement became the standard for all participants who reported eating beef flank in that same dish from that same restaurant. In addition, recipes, including portion sizes, were also obtained from participants to provide reliable intake measures of ethnic foods. If participants could not provide the specific recipe, standardized cookbook recipes for that dish were compared with similar dish recipes 
provided by other participants; in most instances, the standardized recipe was used.

At the end of the $24 \mathrm{~h}$ recall, participants recruited from September 2005 to December 2006 were assessed for prenatal supplement and medication intake during the recall period ( $n$ 138). Given that prenatal supplement use was not obtained from the whole sample and that assessing nutrient intake from prenatal supplements was not the primary objective of the present study, nutrient intake analyses including prenatal supplement use were not conducted.

Data from the $24 \mathrm{~h}$ recalls were entered using the Nutrition Data System for Research (NDSR) software versions $4 \cdot 0 \_35,5 \cdot 0 \_35$ and $6 \cdot 0$ (University of Minnesota, Nutrition Coordinating Center, Minneapolis, MN, USA). The entry of each $24 \mathrm{~h}$ recall was checked three times to ensure that foods, serving sizes and recipes had been entered correctly. Recipes were entered according to the total number of servings prepared and consumed, which were calculated using the serving sizes specified in the NDSR manual (which follows the Dietary Guidelines for Americans 2005 and US Food and Drug Administration serving sizes). For example, if a participant included three cups of uncooked rice in a recipe, this was deemed equivalent to nine cups of cooked rice. Since half a cup of cooked rice was considered a serving for the grain group, the nine cups corresponded to eighteen servings of cooked rice.

Although the NDSR software includes a wide selection of Latino foods, not all foods that participants consumed were available in the database. Food label and ingredient information for ethnic food products unavailable in the database were collected from food wrappers provided by participants, from food packaging at local ethnic convenience stores/bakeries and from manufacturer/ distributor websites, as well as by directly contacting the food manufacturer. All food label and ingredient information was submitted to the University of Minnesota for inclusion into the NDSR database.

\section{Estimation of nutrient and food group intakes}

Nutrient intake was estimated from participants' daily intake data for energy, from six nutrient ratios (i.e. percentage of energy from fat, carbohydrates, protein, SFA, MUFA and PUFA) and from fifty-one individual nutrients (out of the 136 nutrients, nutrient ratios and other food components and indices that NDSR generated). NDSR assigned thirty-three subgroups for grains, seven for fruits, ten for vegetables, twenty-eight for dairy products, twenty-eight for protein and fourteen for fats. These subgroups were further combined, creating a total of fifty food groups.

\section{Statistical analyses}

Analyses were conducted using the Statistical Package for the Social Sciences version 15.0 (IBM Corporation,
Somers, NY, USA). Histograms were generated and the Kolmogorov-Smirnov (K-S) test was used to determine the shape of the distribution of energy-adjusted nutrient intakes and daily serving intakes per food group. Mean and standard deviation were generated to determine the average daily intake of energy and the percentage of energy from fat, carbohydrates, protein, SFA, MUFA and PUFA since they had normal intake distributions within the sample population, as defined by a non-significant $\mathrm{K}-\mathrm{S}$ test. An independent sample Student's $t$ test was conducted to test for ethnic differences.

Tertiles were generated for energy-adjusted nutrients and food groups with skewed intake distributions. Of the fifty-one individual nutrients and fifty food groups examined, five nutrients (fat, protein, thiamin, Se and total sugar) had normal distributions. They were examined as tertiles to maintain consistency with the reporting of results. Participants were assigned to one of four categories on the basis of their consumption level. Those who did not consume the nutrient or food group were categorized as non-consumers. Participants who consumed the nutrient or food group were classified according to consumption tertiles. The $\chi^{2}$ analysis was then used to examine the relationship between nutrient and food group serving intakes and the Latina subgroups.

Nutrient and food group serving intakes that differed significantly or marginally significantly $(P \leq 0 \cdot 10)$ between Latina subgroups were analysed further using multivariate logistic regression to determine whether the Latina subgroups were independent predictors of nutrient and food group serving intakes. Nutrient intake outcomes were categorized in one of two ways (highest intake tertile $v$. low/middle intake tertile or the lowest intake tertile $v$. middle/high intake tertile) on the basis of whether falling in the highest or lowest tertile of intake for each nutrient was optimal or not according to the 2005 Dietary Guidelines' recommendations. Therefore, the OR was expressed in terms of suboptimal nutrient intake. For example, the odds expressed for SFA were in relation to the highest intake of this nutrient, whereas the odds for fibre are in relation to the lowest intake of this nutrient. Food group outcomes were initially classified into consumers and non-consumers. Food groups with $<30 \%$ of non-consumers were reclassified into highest serving intake and no/low/middle intake to avoid a poor model fit resulting from small sample sizes between consumers and non-consumers.

Regression analyses were adjusted for demographic and socio-economic characteristics that were significantly or marginally significantly different $(P \leq 0 \cdot 10)$ between the Latina subgroups. Trimester of enrolment was also included in the analyses to control for dietary differences that may occur because of hormonal changes early in pregnancy (i.e. morning sickness).

Since both Latina subgroups also differed significantly with respect to acculturation proxy characteristics, it was 
necessary to determine whether ethnicity and acculturation variables were strongly related before including them in the final model to avoid multicollinearity. To further determine whether the Latina subgroups were related to acculturation, additional logistic regression analyses were conducted. We first conducted logistic regression analyses for each nutrient and food group serving that was significant or marginally significant in the bivariate analyses using eight different combinations of acculturation proxies and ethnicity as key independent variables. The overall rationale for entering these variables simultaneously was to attenuate the association between ethnicity and nutrient/food group intakes. Second, acculturation proxies were entered into a multivariate logistic regression model predicting the Latina subgroups. Results from these analyses showed that acculturation proxy variables and ethnicity could not be entered together in the same model as the former strongly predicted the participants' ethnic subgroup.

Dietary recall data from eight participants were not included for the following reasons: (i) the $24 \mathrm{~h}$ recall was not completed ( $n$ 2) or the participant was unable to recall information ( $n$ 1); (ii) participants had implausibly low or high energy intakes $(<2092 \mathrm{~kJ}(<500 \mathrm{kcal})$ or $>27196 \mathrm{~kJ}$ ( $>6500 \mathrm{kcal} ; n$ 2)); (iii) participants lived in temporary housing ( $n$ 2); and (iv) participants had medical conditions that limited their energy intake $(n 1)$. As a result, only 233 out of the 241 participants were included in the analyses.

\section{Results}

\section{Participants' characteristics}

Non-Puerto Rican Latinas represented $32 \cdot 6 \%$ of the study sample and included women from Mexico, Central and South America and the Caribbean (Table 1). Comparison of demographic, socio-economic and acculturation characteristics between the two groups showed that nonPuerto Rican Latinas were significantly more likely to be older in age and to have a partner compared with Puerto Rican women. In contrast, Puerto Rican women were significantly more likely than non-Puerto Rican Latinas to be enrolled in food assistance programmes such as the Supplemental Nutrition Assistance Program and WIC, to have been born in the USA, to have lived in the USA longer and to be bilingual.

\section{Nutrient intake}

Table 2 describes the macro- and micronutrient intake characteristics for the whole sample of participants. Significant differences in energy and nutrient intake ratios were found between the Latina subgroups (results not shown). Puerto Ricans had higher mean intakes of energy compared with their non-Puerto Rican counterparts (10718.2 v. 9586.4 kJ). Puerto Ricans also had a higher percentage of energy from fat $(32 \cdot 5 \% v \cdot 27 \cdot 2 \%)$, especially from SFA $(12 \cdot 1 \% v \cdot 9 \cdot 6 \%)$ and MUFA (11·4\%v. 9.5\%). A higher percentage of energy for non-Puerto Rican Latinas came from carbohydrates $(60 \cdot 2 \% v \cdot 54 \cdot 4 \%)$.

Significant differences in nutrient intakes were also found between Puerto Rican and non-Puerto Rican Latinas for twenty-eight of the fifty-one individual nutrients assessed (results not shown). Latina subgroups significantly predicted suboptimal intakes for $68 \%$ of those twenty-eight nutrients (Table 3). Non-Puerto Rican Latinas were more likely to fall in the upper tertile of intake for carbohydrates and starch, whereas Puerto Ricans were more likely to consume higher intakes of fat, including SFA, MUFA and trans fatty acids. However, Puerto Ricans were more likely to fall in the lowest tertile of intake for vegetable protein, fibre (total fibre, insoluble fibre and soluble fibre), total and dietary folate, $\mathrm{Mg}, \mathrm{Mn}, \mathrm{K}$, $\beta$-carotene and water, whereas non-Puerto Rican Latinas were more likely to consume lower intakes of vitamin $\mathrm{B}_{12}$ and $\mathrm{Cu}$. For each nutrient model the Hosmer-Lemeshow statistics indicated that the fit was adequate, with the exception of $\beta$-carotene.

\section{Food group serving intake}

The median daily intakes of all fruits and of all protein foods combined were four and five servings, respectively (Table 4). The median intake for all grain foods combined was over seven servings. By contrast, the median daily vegetable and dairy product intakes were $1 \cdot 3$ and $2 \cdot 0$, respectively. Sugar-sweetened beverages, salty snacks, sugar, candy/sweet sauces/frosting, sweet baked goods and fats/oils were frequently consumed.

Significant differences in serving intakes were found between Puerto Rican and non-Puerto Rican Latinas for twenty-five of the fifty food groups (results not shown). Twenty of the twenty-five food groups had $>30 \%$ of nonconsumers and we classified these food group outcomes as non-consumers and consumers. The Latina subgroups significantly predicted the consumption of twelve of the twenty food groups (Table 5). Non-Puerto Rican Latinas were more likely to consume tortillas, dark green and yellow vegetables (all types of these vegetables as well as only those from fresh or cooked sources) and sugarsweetened products, whereas Puerto Ricans were more likely to consume breakfast cereals, crackers, processed meat, cheese, regular soft drinks, sweetened fruit drinks and sweet baked goods.

The remaining five of the twenty-five food groups were classified into highest and no/low/middle food group servings. The Latina subgroups significantly predicted the odds of falling in the highest food group serving intake tertile for three of the five food groups (Table 5). Non-Puerto Rican Latinas were more likely to fall in the upper tertile of food group serving intakes for all fruits, tomatoes and other non-starchy vegetables. The HosmerLemeshow statistics indicated that all the food group models had an adequate fit. 
Table 1 Dietary intake and participants' characteristics by Latina sub-ethnicity

\begin{tabular}{|c|c|c|c|c|c|c|c|}
\hline \multirow[b]{2}{*}{ Participants' characteristic } & \multicolumn{2}{|c|}{$\begin{array}{l}\text { Whole samplet } \\
\quad(n \text { 233) }\end{array}$} & \multicolumn{2}{|c|}{$\begin{array}{l}\text { Puerto Rican Latinas } \\
\text { (n 157) }\end{array}$} & \multicolumn{2}{|c|}{$\begin{array}{l}\text { Non-Puerto Rican Latinas } \neq \\
(n \text { 76) }\end{array}$} & \multirow[b]{2}{*}{$P$ value ${ }^{\star} \S$} \\
\hline & $n$ & $\%$ & $n$ & $\%$ & $n$ & $\%$ & \\
\hline \multicolumn{8}{|l|}{ Dietary intake characteristics } \\
\hline \multicolumn{8}{|l|}{ Intake day } \\
\hline Weekend day (Saturday and Sunday) & 31 & $13 \cdot 3$ & 23 & $14 \cdot 6$ & 8 & $10 \cdot 5$ & \multirow[t]{2}{*}{$0 \cdot 385$} \\
\hline Weekday & 202 & $86 \cdot 7$ & 134 & $85 \cdot 4$ & 68 & $89 \cdot 5$ & \\
\hline \multicolumn{8}{|l|}{ Age group (years) } \\
\hline$\leq 18$ & 19 & $8 \cdot 2$ & 15 & $9 \cdot 6$ & 4 & $5 \cdot 3$ & \multirow{3}{*}{$0 \cdot 155$} \\
\hline $19-30$ & 181 & $77 \cdot 7$ & 124 & $79 \cdot 0$ & 57 & $75 \cdot 0$ & \\
\hline $31-50$ & 33 & $14 \cdot 2$ & 18 & $11 \cdot 5$ & 15 & $19 \cdot 7$ & \\
\hline \multicolumn{8}{|l|}{ Participants' characteristics } \\
\hline \multicolumn{8}{|l|}{ Trimester at enrolment } \\
\hline First trimester\| & 14 & $6 \cdot 1$ & 11 & $7 \cdot 1$ & 3 & $4 \cdot 0$ & \multirow{3}{*}{0.566} \\
\hline Second trimester & 133 & $57 \cdot 6$ & 87 & $55 \cdot 8$ & 46 & $61 \cdot 3$ & \\
\hline Third trimester & 84 & $36 \cdot 4$ & 58 & $37 \cdot 2$ & 26 & $34 \cdot 7$ & \\
\hline Primiparous & 84 & $36 \cdot 1$ & 55 & $35 \cdot 0$ & 29 & $38 \cdot 2$ & $0 \cdot 641$ \\
\hline Unemployed & 183 & $79 \cdot 2$ & 120 & $77 \cdot 4$ & 63 & 82.9 & 0.335 \\
\hline High school or lower & 190 & $81 \cdot 5$ & 132 & $84 \cdot 1$ & 58 & $76 \cdot 3$ & $0 \cdot 152$ \\
\hline Marital status - no partner & 127 & 54.5 & 102 & $65 \cdot 0$ & 25 & $32 \cdot 9$ & 0.000 \\
\hline WIC - yes & 195 & $83 \cdot 7$ & 138 & $87 \cdot 9$ & 57 & $75 \cdot 0$ & 0.012 \\
\hline SNAP - yes & 116 & $49 \cdot 8$ & 103 & $65 \cdot 6$ & 13 & $17 \cdot 1$ & 0.000 \\
\hline \multicolumn{8}{|l|}{ Monthly household income } \\
\hline \$US 0-\$US 1000 & 125 & $67 \cdot 9$ & 88 & $68 \cdot 2$ & 37 & $67 \cdot 3$ & \multirow[t]{2}{*}{0.900} \\
\hline$>\$$ US 1000 & 59 & $32 \cdot 1$ & 41 & $31 \cdot 8$ & 18 & $32 \cdot 7$ & \\
\hline \multicolumn{8}{|l|}{ Length of time lived in the USA (years) } \\
\hline$<9$ & 112 & $48 \cdot 3$ & 46 & $29 \cdot 5$ & 66 & $86 \cdot 8$ & \multirow[t]{2}{*}{0.000} \\
\hline$\geq 9$ & 120 & $51 \cdot 7$ & 110 & $70 \cdot 5$ & 10 & $13 \cdot 2$ & \\
\hline \multicolumn{8}{|l|}{ Type of birthplacet† } \\
\hline US born & 74 & $36 \cdot 5$ & 71 & $53 \cdot 8$ & 3 & $4 \cdot 2$ & \multirow{3}{*}{0.000} \\
\hline Non-US born - urban & 95 & $46 \cdot 8$ & 46 & $34 \cdot 8$ & 49 & $69 \cdot 0$ & \\
\hline Non-US born - rural & 34 & $16 \cdot 7$ & 15 & $11 \cdot 4$ & 19 & $26 \cdot 8$ & \\
\hline \multicolumn{8}{|l|}{ Language } \\
\hline English only & 6 & $2 \cdot 6$ & 6 & $3 \cdot 8$ & 0 & 0.0 & \multirow{3}{*}{0.000} \\
\hline Bilingual & 126 & $54 \cdot 3$ & 111 & $70 \cdot 7$ & 15 & $20 \cdot 0$ & \\
\hline \multirow[t]{2}{*}{ Spanish only } & 100 & $43 \cdot 1$ & 40 & $25 \cdot 5$ & 60 & $80 \cdot 0$ & \\
\hline & Mean & SD & Mean & SD & Mean & SD & $P$ value ${ }^{*} \S \S$ \\
\hline Maternal age & $24 \cdot 62$ & $5 \cdot 55$ & 23.92 & $5 \cdot 43$ & $26 \cdot 07$ & $5 \cdot 55$ & 0.005 \\
\hline Household sizełł & 4.08 & $1 \cdot 89$ & 3.92 & $1 \cdot 86$ & $4 \cdot 40$ & 1.92 & 0.072 \\
\hline
\end{tabular}

WIC, Special Supplemental Nutrition Program for Women, Infants, and Children; SNAP, Supplemental Nutrition Assistance Program.

*Significant at the 0.05 level.

tNo more than $1 \%$ had missing values, except for monthly household income $(n 184)$ and type of birthplace ( $n$ 203) because many participants did not know their household income or if their birthplace was urban/semi-urban or rural.

flncludes participants who identified themselves as (\% of the whole sample): Mexican (12.0\%), Peruvian (6.4\%), Guatemalan (3.0\%), Dominican (2.6\%), Honduran $(2.6 \%)$, Colombian $(1.7 \%)$, El Salvadorian $(1.3 \%)$, Uruguayan $(0.9 \%)$, Ecuadorian $(0.9 \%)$, Argentinean $(0.4 \%)$, Bolivian $(0.4 \%)$ and Cuban $(0.4 \%)$.

\$The $\chi^{2}$ analysis was conducted to determine differences between ethnic subgroups.

$\|$ Became an exclusion criterion for the longitudinal study.

TBased on median time spent in the USA for the whole sample.

t+Non-US born includes being born in Puerto Rico.

\#łIncludes participant.

$\S \S$ Student $t$ tests were conducted to determine differences between ethnic subgroups.

\section{Discussion}

Findings from the present study show that Latina subgroups living in the same geographical area have substantially different nutrient and food group serving intake patterns. We showed that non-Puerto Rican Latinas compared with Puerto Ricans consumed more fruit and vegetables and fewer processed grains (i.e. breakfast cereals, crackers), processed meat, cheese, artificial beverages (i.e. regular soft drinks, sweetened fruit drinks) and sweet baked goods. Consistent with this, non-Puerto Rican Latinas had higher intakes of key vitamins, minerals and fibre but lower intakes of fats (saturated, monounsaturated and trans fats) compared with Puerto Ricans. One explanation may be the differences in acculturation level between the ethnic groups. In our study, non-Puerto Rican Latinas compared with Puerto Ricans were significantly more likely to be born outside the USA, to live for less duration in the USA and to speak only Spanish. On the basis of these differences in baseline characteristics of the accepted proxy measures for acculturation, the non-Puerto Rican Latinas in the present study were much less acculturated. This conclusion of acculturation was strongly supported through the multivariate logistic 
Table 2 Descriptive characteristics for macro- and micronutrient intakes for the whole sample $(n$ 233)†

\begin{tabular}{|c|c|c|c|c|c|}
\hline & Mean & SD & Median & Minimum & Maximum \\
\hline \multicolumn{6}{|l|}{ Macronutrients (\% of energy) } \\
\hline Carbohydrates & $56 \cdot 3$ & $10 \cdot 5$ & $56 \cdot 8$ & $16 \cdot 1$ & $90 \cdot 1$ \\
\hline Fat & $30 \cdot 7$ & 8.5 & $30 \cdot 4$ & $6 \cdot 8$ & $66 \cdot 6$ \\
\hline Protein & $14 \cdot 0$ & $3 \cdot 5$ & $14 \cdot 1$ & $5 \cdot 2$ & $30 \cdot 7$ \\
\hline Saturated fat & $11 \cdot 3$ & $4 \cdot 1$ & $11 \cdot 1$ & $1 \cdot \overline{5}$ & $25 \cdot 7$ \\
\hline Monounsaturated fat & $10 \cdot 8$ & $3 \cdot 7$ & $10 \cdot 5$ & $3 \cdot 1$ & $29 \cdot 4$ \\
\hline Polyunsaturated fat & $5 \cdot 8$ & $2 \cdot 8$ & $5 \cdot 2$ & $1 \cdot 1$ & $20 \cdot 9$ \\
\hline \multicolumn{6}{|l|}{ Macronutrients $(\mathrm{g})$} \\
\hline Carbohydrates & $345 \cdot 3$ & $142 \cdot 0$ & $329 \cdot 1$ & $89 \cdot 4$ & $1143 \cdot 0$ \\
\hline Fat & $86 \cdot 2$ & $42 \cdot 2$ & $78 \cdot 1$ & $9 \cdot 0$ & $227 \cdot 7$ \\
\hline Protein & $85 \cdot 9$ & $35 \cdot 1$ & $81 \cdot 4$ & $15 \cdot 0$ & $251 \cdot 9$ \\
\hline Animal protein & $57 \cdot 2$ & $29 \cdot 6$ & $51 \cdot 9$ & $0 \cdot 7$ & $196 \cdot 1$ \\
\hline Vegetable protein & $28 \cdot 6$ & $14 \cdot 2$ & $25 \cdot 5$ & $3 \cdot 7$ & $82 \cdot 6$ \\
\hline \multicolumn{6}{|l|}{ Fatty acids } \\
\hline SFA (g) & $31 \cdot 9$ & $18 \cdot 1$ & $28 \cdot 8$ & $1 \cdot 9$ & $106 \cdot 9$ \\
\hline MUFA (g) & $30 \cdot 2$ & $15 \cdot 5$ & $27 \cdot 5$ & $4 \cdot 1$ & $85 \cdot 4$ \\
\hline PUFA (g) & $16 \cdot 2$ & $10 \cdot 1$ & $14 \cdot 3$ & $1 \cdot 2$ & $62 \cdot 4$ \\
\hline Trans fatty acids (g) & 4.5 & $3 \cdot 7$ & $3 \cdot 4$ & $0 \cdot \overline{0}$ & $23 \cdot 8$ \\
\hline$n-3$ fatty acids $(\mathrm{g})$ & $1 \cdot 7$ & $1 \cdot 0$ & $1 \cdot 5$ & $0 \cdot 2$ & $6 \cdot 1$ \\
\hline \multicolumn{6}{|l|}{ Fibre } \\
\hline Total fibre $(\mathrm{g})$ & $17 \cdot 8$ & $10 \cdot 4$ & $15 \cdot 5$ & $2 \cdot 0$ & $57 \cdot 1$ \\
\hline Insoluble fibre (g) & $12 \cdot 2$ & $7 \cdot 8$ & $10 \cdot 5$ & 0.9 & $38 \cdot 6$ \\
\hline Soluble fibre $(\mathrm{g})$ & $5 \cdot 3$ & $3 \cdot 1$ & $4 \cdot 7$ & $0 \cdot 6$ & $22 \cdot 9$ \\
\hline \multicolumn{6}{|l|}{ Fat-soluble vitamins } \\
\hline Vitamin A ( $\mu$ g RAE) & $768 \cdot 0$ & $693 \cdot 4$ & $578 \cdot 6$ & $10 \cdot 1$ & $6385 \cdot 7$ \\
\hline Vitamin $D(\mu \mathrm{g})$ & $6 \cdot 5$ & $5 \cdot 4$ & $5 \cdot 3$ & $0 \cdot 0$ & $30 \cdot 1$ \\
\hline Vitamin K $(\mu \mathrm{g})$ & $57 \cdot 0$ & $56 \cdot 0$ & $41 \cdot 8$ & $3 \cdot 5$ & $422 \cdot 4$ \\
\hline Vitamin E (mg) & $6 \cdot 5$ & $4 \cdot 6$ & $5 \cdot 8$ & $0 \cdot 3$ & $48 \cdot 2$ \\
\hline \multicolumn{6}{|l|}{ Water-soluble vitamins } \\
\hline Vitamin C (mg) & $173 \cdot 6$ & $157 \cdot 0$ & $127 \cdot 8$ & $0 \cdot 7$ & $948 \cdot 7$ \\
\hline Total folate $(\mu \mathrm{g})$ & $610 \cdot 1$ & $340 \cdot 7$ & $529 \cdot 2$ & $103 \cdot 6$ & $1806 \cdot 0$ \\
\hline Dietary folate $(\mu \mathrm{g})$ & 284.9 & $185 \cdot 2$ & $238 \cdot 7$ & $31 \cdot 9$ & $1169 \cdot 3$ \\
\hline Folic acid $(\mu \mathrm{g})$ & $768 \cdot 0$ & $693 \cdot 4$ & $578 \cdot 6$ & $10 \cdot 1$ & $6385 \cdot 7$ \\
\hline Niacin (mg) & $24 \cdot 1$ & $11 \cdot 7$ & $22 \cdot 6$ & $5 \cdot 2$ & $95 \cdot 0$ \\
\hline Pantothenic acid (mg) & $5 \cdot 8$ & $3 \cdot 4$ & $5 \cdot 2$ & $1 \cdot \overline{0}$ & $37 \cdot 1$ \\
\hline Riboflavin (mg) & $2 \cdot 6$ & $1 \cdot 4$ & $2 \cdot 3$ & 0.5 & $10 \cdot 1$ \\
\hline Thiamin $(\mathrm{mg})$ & $2 \cdot 2$ & $1 \cdot 0$ & $2 \cdot 1$ & $0 \cdot 6$ & $7 \cdot 1$ \\
\hline Vitamin $B_{6}(\mathrm{mg})$ & $2 \cdot 3$ & $1 \cdot 3$ & $2 \cdot 0$ & 0.4 & $9 \cdot 9$ \\
\hline Vitamin $B_{12}(\mu \mathrm{g})$ & $5 \cdot 6$ & $4 \cdot 4$ & $4 \cdot 8$ & $0 \cdot 0$ & $32 \cdot 4$ \\
\hline \multicolumn{6}{|l|}{ Minerals } \\
\hline $\mathrm{Ca}(\mathrm{mg})$ & $1033 \cdot 7$ & $628 \cdot 7$ & $867 \cdot 6$ & $146 \cdot 8$ & $3672 \cdot 8$ \\
\hline $\mathrm{Cu}(\mu \mathrm{g})$ & $1297 \cdot 1$ & $669 \cdot 1$ & $1170 \cdot 0$ & $240 \cdot 0$ & $6640 \cdot 0$ \\
\hline $\mathrm{Fe}(\mathrm{mg})$ & $18 \cdot 7$ & $10 \cdot 0$ & $16 \cdot 6$ & $5 \cdot 5$ & $74 \cdot 3$ \\
\hline $\mathrm{Mg}(\mathrm{mg})$ & $290 \cdot 6$ & $133 \cdot 3$ & $264 \cdot 1$ & $87 \cdot 5$ & $1038 \cdot 4$ \\
\hline $\mathrm{Mn}(\mathrm{mg})$ & $3 \cdot 3$ & $1 \cdot 8$ & $3 \cdot 0$ & $0 \cdot 3$ & $10 \cdot 0$ \\
\hline$P(m g)$ & $1410 \cdot 6$ & $611 \cdot 4$ & $1319 \cdot 5$ & $304 \cdot 4$ & $3900 \cdot 7$ \\
\hline$K(g)$ & $3 \cdot 0$ & $1 \cdot 6$ & $2 \cdot 7$ & $0 \cdot 6$ & $12 \cdot 4$ \\
\hline $\operatorname{Se}(\mu g)$ & $129 \cdot 7$ & $57 \cdot 0$ & $120 \cdot 1$ & $22 \cdot 2$ & $424 \cdot 7$ \\
\hline $\mathrm{Na}(\mathrm{g})$ & $4 \cdot 3$ & $2 \cdot 2$ & $3 \cdot 8$ & $0 \cdot 6$ & $12 \cdot 8$ \\
\hline $\mathrm{Zn}(\mathrm{mg})$ & $12 \cdot 0$ & $6 \cdot 7$ & $10 \cdot 9$ & $1 \cdot 8$ & $68 \cdot 0$ \\
\hline \multicolumn{6}{|l|}{ Simple and complex sugars } \\
\hline Total sugar $(\mathrm{g})$ & $162 \cdot 5$ & $85 \cdot 4$ & $148 \cdot 9$ & $22 \cdot 5$ & $698 \cdot 0$ \\
\hline Fructose $(\mathrm{g})$ & $39 \cdot 2$ & $29 \cdot 5$ & $31 \cdot 7$ & $0 \cdot 4$ & $192 \cdot 6$ \\
\hline Galactose (g) & 0.2 & 0.4 & 0.1 & $0 \cdot 0$ & $2 \cdot 9$ \\
\hline Glucose $(\mathrm{g})$ & $35 \cdot 9$ & $25 \cdot 4$ & $31 \cdot 2$ & $1 \cdot 2$ & $179 \cdot 3$ \\
\hline Lactose (g) & $22 \cdot 1$ & $22 \cdot 4$ & $15 \cdot \overline{5}$ & $0 . \overline{0}$ & $110 \cdot 6$ \\
\hline Maltose (g) & $2 \cdot 4$ & $3 \cdot 2$ & $1 \cdot 6$ & $0 \cdot 0$ & $33 \cdot 0$ \\
\hline Sucrose (g) & $62 \cdot 6$ & $48 \cdot 1$ & $51 \cdot 4$ & $1 \cdot 0$ & 358.5 \\
\hline Starch $(\mathrm{g})$ & $148 \cdot 8$ & $71 \cdot 1$ & $131 \cdot 3$ & $29 \cdot 3$ & $358 \cdot 2$ \\
\hline \multicolumn{6}{|l|}{ Carotenoids } \\
\hline$\beta$-Carotene $(\mu \mathrm{g})$ & $2639 \cdot 9$ & $6424 \cdot 7$ & $888 \cdot 0$ & $19 \cdot 9$ & $73948 \cdot 0$ \\
\hline Lutein and zeaxanthin $(\mu \mathrm{g})$ & $1090 \cdot 5$ & $992 \cdot 5$ & $795 \cdot 3$ & $14 \cdot 9$ & $5448 \cdot 4$ \\
\hline Lycopene $(\mu \mathrm{g})$ & $5031 \cdot 0$ & $8686 \cdot 5$ & 2341.5 & $0 \cdot 0$ & $79324 \cdot 0$ \\
\hline \multicolumn{6}{|l|}{ Other nutrients } \\
\hline Cholesterol (mg) & $375 \cdot 8$ & $286 \cdot 8$ & $290 \cdot 1$ & $5 \cdot 8$ & $1370 \cdot 3$ \\
\hline Caffeine $(\mu \mathrm{g})$ & $31 \cdot 6$ & $58 \cdot 0$ & $4 \cdot 6$ & $0 \cdot 0$ & $355 \cdot 2$ \\
\hline Water $(\mathrm{l}) \ddagger$ & $2 \cdot 6$ & $1 \cdot 1$ & $2 \cdot 3$ & $0 \cdot 7$ & $9 \cdot 8$ \\
\hline
\end{tabular}

RAE, retinol activity equivalents.

+Values of 0 indicate small nutrient intakes close to 0 .

‡lncludes water from food and beverages, as well as drinking water. 
Table 3 Unadjusted and adjusted OR for suboptimal energy-adjusted nutrient intake among non-Puerto Rican (compared with Puerto Rican) Latinas

\begin{tabular}{|c|c|c|c|c|c|}
\hline Nutrient & OR (unadjusted) & $95 \% \mathrm{Cl}$ & OR (adjusted) + & $95 \% \mathrm{Cl}$ & $\begin{array}{c}\text { Hosmer-Lemeshow } \\
\text { statistic } \neq\end{array}$ \\
\hline \multicolumn{6}{|c|}{ Odds of falling in the highest intake tertile } \\
\hline \multicolumn{6}{|l|}{ Macronutrients } \\
\hline Carbohydrates (g) & $2 \cdot 55$ & $1 \cdot 43,4 \cdot 52^{*}$ & $2 \cdot 79$ & $1 \cdot 37,5 \cdot 70^{\star}$ & 0.58 \\
\hline Fat $(g)$ & 0.42 & $0.22,0.79^{*}$ & $0 \cdot 37$ & $0.17,0.79^{*}$ & 0.55 \\
\hline \multicolumn{6}{|l|}{ Fatty acids } \\
\hline SFA (g) & $0 \cdot 33$ & $0.17,0.64^{*}$ & $0 \cdot 24$ & $0.11,0.53^{*}$ & $0 \cdot 70$ \\
\hline MUFA (g) & $0 \cdot 38$ & $0 \cdot 20,0 \cdot 72^{*}$ & 0.38 & $0 \cdot 18,0 \cdot 82^{*}$ & 0.85 \\
\hline Trans fatty acids $(\mathrm{g})$ & $0 \cdot 34$ & $0.17,0.65^{\star}$ & $0 \cdot 21$ & $0.09,0.47^{\star}$ & $0 \cdot 16$ \\
\hline \multicolumn{6}{|l|}{ Minerals } \\
\hline $\mathrm{Na}(\mathrm{g})$ & $0 \cdot 67$ & $0 \cdot 37,1 \cdot 22$ & $1 \cdot 14$ & $0 \cdot 54,2 \cdot 40$ & $0 \cdot 72$ \\
\hline \multicolumn{6}{|l|}{ Simple and complex sugars } \\
\hline Glucose (g) & $0 \cdot 76$ & $0 \cdot 42,1 \cdot 37$ & 0.94 & $0.45,1.94$ & 0.94 \\
\hline Maltose $(\mathrm{g})$ & $0 \cdot 91$ & $0.50,1.63$ & 0.69 & $0.33,1.43$ & $0 \cdot 77$ \\
\hline Starch $(g)$ & $2 \cdot 68$ & $1 \cdot 51,4 \cdot 76^{\star}$ & $3 \cdot 40$ & $1 \cdot 61,7 \cdot 16^{\star}$ & $0 \cdot 79$ \\
\hline \multicolumn{6}{|l|}{ Other nutrients } \\
\hline Caffeine $(\mu \mathrm{g})$ & $0 \cdot 75$ & $0.37,1.52$ & $0 \cdot 73$ & $0 \cdot 31,1 \cdot 76$ & $0 \cdot 14$ \\
\hline \multicolumn{6}{|c|}{ Odds of falling in the lowest intake tertile } \\
\hline Vegetable protein $(\mathrm{g})$ & $0 \cdot 26$ & $0.13,0.52^{*}$ & $0 \cdot 21$ & $0.09,0.47^{*}$ & $0 \cdot 31$ \\
\hline \multicolumn{6}{|l|}{ Fibre } \\
\hline Total fibre $(\mathrm{g})$ & $0 \cdot 10$ & $0.04,0.25^{\star}$ & 0.09 & $0.03,0.25^{\star}$ & 0.59 \\
\hline Insoluble fibre (g) & $0 \cdot 14$ & $0.06,0.32^{*}$ & $0 \cdot 11$ & $0 \cdot 04,0 \cdot 28^{*}$ & 0.09 \\
\hline Soluble fibre $(\mathrm{g})$ & $0 \cdot 29$ & $0 \cdot 15,0.57^{*}$ & $0 \cdot 31$ & $0 \cdot 14,0.68^{*}$ & $0 \cdot 71$ \\
\hline \multicolumn{6}{|l|}{ Fat-soluble vitamins } \\
\hline Vitamin $\mathrm{K}(\mu \mathrm{g})$ & 0.67 & $0 \cdot 37,1 \cdot 22$ & 0.73 & $0.35,1 \cdot 50$ & 0.96 \\
\hline \multicolumn{6}{|l|}{ Water-soluble vitamins } \\
\hline Total folate $(\mu \mathrm{g})$ & $0 \cdot 37$ & $0 \cdot 19,0 \cdot 70^{\star}$ & $0 \cdot 32$ & $0 \cdot 15,0 \cdot 71^{*}$ & $0 \cdot 75$ \\
\hline Dietary folate $(\mu \mathrm{g})$ & $0 \cdot 20$ & $0 \cdot 10,0.43^{*}$ & $0 \cdot 22$ & $0.09,0.51^{*}$ & $0 \cdot 87$ \\
\hline Pantothenic acid $(\mu \mathrm{g})$ & $0 \cdot 47$ & $0 \cdot 25,0.87^{\star}$ & 0.48 & $0 \cdot 23,1 \cdot 02^{\star \star}$ & 0.36 \\
\hline Riboflavin (mg) & 0.67 & $0 \cdot 37,1 \cdot 22$ & 0.93 & $0.45,1.93$ & $0 \cdot 13$ \\
\hline Vitamin $B_{12}(\mu \mathrm{g})$ & $2 \cdot 34$ & $1 \cdot 32,4 \cdot 15^{\star}$ & $2 \cdot 80$ & $1 \cdot 34,5 \cdot 86^{\star}$ & 0.23 \\
\hline \multicolumn{6}{|l|}{ Minerals } \\
\hline $\mathrm{Cu}(\mu \mathrm{g})$ & $5 \cdot 84$ & $2 \cdot 72,12 \cdot 53^{*}$ & $5 \cdot 37$ & $2 \cdot 21,13 \cdot 04^{*}$ & 0.95 \\
\hline $\mathrm{Mg}(\mathrm{mg})$ & $0 \cdot 15$ & $0.07,0.33^{\star}$ & $0 \cdot 19$ & $0 \cdot 08,0 \cdot 46^{\star}$ & 0.97 \\
\hline $\mathrm{Mn}(\mathrm{mg})$ & $0 \cdot 33$ & $0 \cdot 17,0.64^{*}$ & $0 \cdot 24$ & $0 \cdot 11,0 \cdot 54^{\star}$ & 0.36 \\
\hline$P(\mathrm{mg})$ & 0.57 & $0 \cdot 31,1 \cdot 05^{\star \star}$ & 0.91 & $0.43,1.92$ & $0 \cdot 81$ \\
\hline$K(g)$ & $0 \cdot 30$ & $0 \cdot 15,0.59^{\star}$ & $0 \cdot 34$ & $0 \cdot 15,0 \cdot 77^{*}$ & 0.48 \\
\hline \multicolumn{6}{|l|}{ Carotenoids } \\
\hline$\beta$-Carotene $(\mu \mathrm{g})$ & $0 \cdot 23$ & $0 \cdot 11,0.46^{*}$ & $0 \cdot 39$ & $0 \cdot 17,0 \cdot 88^{\star}$ & 0.04 \\
\hline Lutein and zeaxanthin $(\mu \mathrm{g})$ & 0.45 & $0 \cdot 24,0.85^{\star}$ & 0.49 & $0 \cdot 23,1 \cdot 03^{\star \star}$ & $0 \cdot 87$ \\
\hline \multicolumn{6}{|l|}{ Other nutrients } \\
\hline Water (I) & $0 \cdot 33$ & $0.17,0.64^{*}$ & $0 \cdot 28$ & $0.13,0.62^{*}$ & $0 \cdot 26$ \\
\hline
\end{tabular}

${ }^{*} P \leq 0 \cdot 05 ;{ }^{* *} P \leq 0 \cdot 10$.

†Adjusted for education, marital status, enrolment in the Special Supplemental Nutrition Program for Women, Infants, and Children and in the Supplemental Nutrition Assistance Program, maternal age, pregnancy trimester at enrolment, number of people in the house.

$\ddagger$ The Hosmer-Lemeshow statistic was used to evaluate the fit of the multivariate logistic regression models.

regression analyses we conducted, which showed that the acculturation proxies and Latina subgroups were strongly related. Reviews by Ayala et $a l^{(26)}$ and by PérezEscamilla and Putnick ${ }^{(27)}$ on studies examining the link between acculturation and diet among Latinos concluded that acculturation affects dietary quality negatively. Both found that less acculturation was related to higher consumption of fruit, rice and beans and to lower consumption of sugar and sugar-sweetened beverages. Although both included studies conducted among men and/or women, these overall findings, as well as others that specifically focused on pregnant women of Mexican descent ${ }^{(16)}$, support our findings. In our study, nonPuerto Rican Latinas had nutrient and food group serving intake patterns that reflected healthier dietary behaviours compared with their more acculturated Puerto Rican counterparts.

Compared with the national study by Abrams and Guendelman ${ }^{(17)}$, which was published 16 years ago, mean intakes in our study for energy $(10349 v .8091 .9 \mathrm{~kJ}$, respectively), carbohydrates (345 v. $220 \mathrm{~g}$, respectively) and $\mathrm{Fe}(18.7 v \cdot 12.2 \mathrm{mg}$, respectively) were higher, but intakes of dietary folate ( $285 v .287 \mu \mathrm{g}$, respectively) and Ca (1034 v. $952 \mathrm{mg}$, respectively) were almost identical. Compared with other studies, energy from saturated fat and protein intakes from the present study were similar to those reported by Harley et al. ${ }^{(16)}$ and carbohydrate and cholesterol intakes were similar to those reported by 
Table 4 Descriptive characteristics for daily food group serving intakes among consumerstł

\begin{tabular}{|c|c|c|c|c|c|c|}
\hline & $n$ & Mean & SD & Median & Minimum & Maximum \\
\hline \multicolumn{7}{|l|}{ Grains } \\
\hline Rice & 123 & $3 \cdot 1$ & $2 \cdot 1$ & $2 \cdot 4$ & $0 \cdot 1$ & $11 \cdot 0$ \\
\hline Tortillas & 37 & $3 \cdot 9$ & $2 \cdot 7$ & $3 \cdot 4$ & $0 \cdot 4$ & $11 \cdot 3$ \\
\hline Breakfast cereals & 86 & $2 \cdot 3$ & $1 \cdot 5$ & $1 \cdot 9$ & $0 \cdot 1$ & $10 \cdot 7$ \\
\hline Bread & 159 & $4 \cdot 1$ & $3 \cdot 4$ & $2 \cdot 7$ & $0 \cdot 2$ & $22 \cdot 0$ \\
\hline Pasta & 70 & $1 \cdot 9$ & $1 \cdot 4$ & $1 \cdot 4$ & 0.2 & $5 \cdot 2$ \\
\hline Crackers & 33 & $1 \cdot 0$ & $0 \cdot 6$ & $0 \cdot 8$ & $0 \cdot 3$ & $3 \cdot 0$ \\
\hline All grains & 230 & $7 \cdot 9$ & $4 \cdot 4$ & $7 \cdot 2$ & $0 \cdot 2$ & $24 \cdot 8$ \\
\hline \multicolumn{7}{|l|}{ Fruits } \\
\hline Fruit (all fruits, no juices) & 124 & $3 \cdot 1$ & $3 \cdot 3$ & $2 \cdot 0$ & $0 \cdot 1$ & $24 \cdot 1$ \\
\hline Fruit juice (100\% citrus and non-citrus fruit juice) & 120 & $4 \cdot 6$ & $3 \cdot 3$ & $4 \cdot 0$ & $0 \cdot 0$ & $18 \cdot 0$ \\
\hline Fruit and fruit juices (100\% citrus and non-citrus fruit juice) & 170 & $5 \cdot 0$ & 4.5 & $4 \cdot 0$ & $0 \cdot 0$ & $31 \cdot 8$ \\
\hline Fried fruit (fried apple, banana, plantains, etc.) & 26 & $3 \cdot 1$ & $2 \cdot 4$ & $2 \cdot 8$ & $0 \cdot 4$ & $10 \cdot 8$ \\
\hline All fruits (all combined, excluding fried fruit) & 171 & $5 \cdot 0$ & $4 \cdot 5$ & $4 \cdot 0$ & $0 \cdot 0$ & $31 \cdot 8$ \\
\hline \multicolumn{7}{|l|}{ Vegetables } \\
\hline All dark green and yellow vegetables & 65 & $0 \cdot 8$ & $1 \cdot 3$ & $0 \cdot 4$ & $0 \cdot 0$ & $7 \cdot 2$ \\
\hline $\begin{array}{l}\text { Dark green and yellow vegetables (raw, cooked or included in } \\
\text { homemade recipes) }\end{array}$ & 45 & $1 \cdot 0$ & $1 \cdot 4$ & $0 \cdot 4$ & $0 \cdot 0$ & $7 \cdot \overline{2}$ \\
\hline $\begin{array}{l}\text { Dark green and yellow vegetables (from fast-food restaurants, } \\
\text { processed or canned foods, etc.) }\end{array}$ & 15 & $0 \cdot 4$ & $0 \cdot 9$ & $0 \cdot 0$ & $0 \cdot 1$ & $3 \cdot 2$ \\
\hline Tomatoes & 181 & $0 \cdot 6$ & $0 \cdot 7$ & 0.4 & $0 \cdot 0$ & $3 \cdot 0$ \\
\hline $\begin{array}{l}\text { Other non-starchy vegetables (e.g. beets, cabbage, mung } \\
\text { bean sprouts, summer squash, etc.) }\end{array}$ & 197 & $0 \cdot 7$ & $0 \cdot 9$ & $0 \cdot 4$ & $0 \cdot 0$ & $5 \cdot 2$ \\
\hline White potatoes & 76 & $1 \cdot 4$ & $1 \cdot 6$ & $0 \cdot 7$ & $0 \cdot 0$ & $9 \cdot 0$ \\
\hline Fried potatoes & 30 & $1 \cdot 3$ & $0 \cdot 8$ & $1 \cdot 3$ & $0 \cdot 4$ & $3 \cdot 0$ \\
\hline $\begin{array}{l}\text { Other starchy vegetables (e.g. corn, immature lima beans, } \\
\text { lentil sprouts, peas, etc.) }\end{array}$ & 135 & $0 \cdot 3$ & $0 \cdot 7$ & $0 \cdot 0$ & $0 \cdot 0$ & $4 \cdot 2$ \\
\hline All vegetables (excluding fried potatoes) & 217 & $2 \cdot 1$ & $2 \cdot 2$ & $1 \cdot 3$ & $0 \cdot 0$ & $16 \cdot 7$ \\
\hline \multicolumn{7}{|l|}{ Protein } \\
\hline Meat (beef, lamb, veal, pork, organ meat) & 166 & $2 \cdot 8$ & $2 \cdot 7$ & $2 \cdot 2$ & $0 \cdot 0$ & $15 \cdot 8$ \\
\hline Poultry & 95 & $3 \cdot 2$ & $2 \cdot 5$ & $3 \cdot 0$ & $0 \cdot 0$ & $13 \cdot 3$ \\
\hline Eggs & 111 & $1 \cdot 7$ & $1 \cdot 1$ & $1 \cdot 7$ & $0 \cdot 0$ & $6 \cdot 1$ \\
\hline Fish & 25 & $3 \cdot 2$ & $2 \cdot 4$ & $2 \cdot 7$ & $0 \cdot 7$ & $9 \cdot 8$ \\
\hline Beans & 67 & $1 \cdot 0$ & $1 \cdot 0$ & $0 \cdot 6$ & $0 \cdot 0$ & $5 \cdot 5$ \\
\hline Processed meat & 103 & $1 \cdot 9$ & $1 \cdot 8$ & $1 \cdot 5$ & $0 \cdot 0$ & $14 \cdot 5$ \\
\hline Nuts and seeds & 7 & $1 \cdot 9$ & $3 \cdot 0$ & $1 \cdot 0$ & $0 \cdot 2$ & $8 \cdot 7$ \\
\hline All protein foods & 227 & $5 \cdot 8$ & $3 \cdot 7$ & $5 \cdot 0$ & $0 \cdot 1$ & $25 \cdot 7$ \\
\hline \multicolumn{7}{|l|}{ Dairy } \\
\hline Milk and cream & 192 & 1.9 & $1 \cdot 7$ & 1.5 & $0 \cdot 0$ & $8 \cdot 6$ \\
\hline Sweetened milk beverage powder (e.g. cocoa) & 24 & $0 \cdot 8$ & $0 \cdot 8$ & 0.5 & $0 \cdot 1$ & $3 \cdot 7$ \\
\hline Cheese & 146 & $1 \cdot 1$ & $1 \cdot 3$ & $0 \cdot 8$ & $0 \cdot 0$ & $12 \cdot 9$ \\
\hline Yoghurt & 11 & $0 \cdot 7$ & $0 \cdot 3$ & $0 \cdot 6$ & 0.5 & $1 \cdot 3$ \\
\hline Dairy desserts & 15 & $1 \cdot 4$ & 1.5 & $1 \cdot 0$ & $0 \cdot 0$ & $6 \cdot 0$ \\
\hline All dairy & 222 & $2 \cdot 7$ & $2 \cdot 2$ & $2 \cdot 0$ & 0.0 & $14 \cdot 1$ \\
\hline \multicolumn{7}{|l|}{ Beverages } \\
\hline Regular soft drinks & 86 & $2 \cdot 4$ & $2 \cdot 3$ & $1 \cdot 5$ & $0 \cdot 1$ & $16 \cdot 9$ \\
\hline Diet soft drinks & 4 & $2 \cdot 0$ & $2 \cdot 0$ & $1 \cdot 2$ & $0 \cdot 7$ & $5 \cdot 0$ \\
\hline Sweetened fruit drinks & 89 & $2 \cdot 3$ & $1 \cdot 6$ & $2 \cdot 0$ & $0 \cdot 2$ & $7 \cdot 7$ \\
\hline Water & 189 & $3 \cdot 6$ & $3 \cdot 1$ & $2 \cdot 9$ & $0 \cdot 1$ & $16 \cdot 0$ \\
\hline Coffee & 44 & $0 \cdot 7$ & $0 \cdot 8$ & 0.5 & $0 \cdot 0$ & $3 \cdot 7$ \\
\hline Tea & 22 & $2 \cdot 4$ & $1 \cdot 6$ & $1 \cdot 9$ & $0 \cdot 6$ & $6 \cdot 0$ \\
\hline Beer and ale & 13 & 0.5 & 0.2 & 0.5 & $0 \cdot 3$ & $0 \cdot 7$ \\
\hline Wine & 6 & $0 \cdot 1$ & $0 \cdot 2$ & $0 \cdot 1$ & $0 \cdot 0$ & 0.5 \\
\hline \multicolumn{7}{|l|}{ Miscellaneous } \\
\hline Salty Snacks & 23 & $2 \cdot 0$ & $1 \cdot 6$ & $1 \cdot 1$ & 0.9 & $8 \cdot 0$ \\
\hline Sugar & 107 & $4 \cdot 6$ & $5 \cdot 6$ & $2 \cdot 1$ & $0 \cdot 0$ & $26 \cdot 1$ \\
\hline Syrup and jellies & 41 & $0 \cdot 3$ & $0 \cdot 2$ & $0 \cdot 2$ & 0.0 & $1 \cdot 0$ \\
\hline Candy, sweet sauces, frosting & 23 & $1 \cdot 2$ & $1 \cdot 0$ & $1 \cdot 2$ & $0 \cdot 0$ & $4 \cdot 0$ \\
\hline Sweet baked goods & 59 & $1 \cdot 7$ & $1 \cdot 0$ & $1 \cdot \overline{6}$ & $0 \cdot 2$ & $4 \cdot 8$ \\
\hline Salad dressings & 63 & $1 \cdot 0$ & $1 \cdot 0$ & $0 \cdot 8$ & $0 \cdot 1$ & $5 \cdot 5$ \\
\hline Fats and oils & 218 & $4 \cdot 4$ & $4 \cdot 6$ & $2 \cdot 7$ & $0 \cdot 0$ & $31 \cdot 2$ \\
\hline
\end{tabular}

†Values of 0 indicate small serving sizes close to 0.

¥The $\%$ of non-consumers ranged from $1 \cdot 3 \%$ to $85 \cdot 8 \%$ for the grain group, from $26 \cdot 6 \%$ to $88.8 \%$ for the fruit group, from $6 \cdot 7 \%$ to $93.6 \%$ for the vegetable group, from $2.6 \%$ to $97.0 \%$ for the protein group, from $4.7 \%$ to $93.6 \%$ for the dairy group, from $18.9 \%$ to $98 \cdot 3 \%$ for the beverage group and from $6.4 \%$ to $90 \cdot 1 \%$ for the miscellaneous group.

Guiterrez $^{(22)}$. Among food groups, the mean dairy serving intakes from our study were similar to those reported by Guendelman and Abrams ${ }^{(21)}(2 \cdot 7 v \cdot 2 \cdot 4$, respectively) and by Harley et al. for Mexican-born women, whereas protein serving intakes were much higher among our groups compared with the intakes reported by Guendelman and 
Table 5 Unadjusted and adjusted OR for food group intake among non-Puerto Rican (compared with Puerto Rican) Latinas

\begin{tabular}{|c|c|c|c|c|c|}
\hline Nutrient & $\begin{array}{c}\text { OR } \\
\text { (unadjusted) }\end{array}$ & $95 \% \mathrm{Cl}$ & $\begin{array}{c}\text { OR } \\
\text { (adjusted) }\end{array}$ & $95 \% \mathrm{Clt}$ & $\begin{array}{l}\text { Hosmer-Lemeshow } \\
\text { statistic } \neq\end{array}$ \\
\hline \multicolumn{6}{|c|}{ Odds of being a consumer } \\
\hline \multicolumn{6}{|l|}{ Grains } \\
\hline Tortillas & $22 \cdot 11$ & $8 \cdot 13,60 \cdot 13^{*}$ & $34 \cdot 22$ & $8 \cdot 71,134 \cdot 46^{*}$ & 0.53 \\
\hline Breakfast cereals & 0.45 & $0 \cdot 24,0 \cdot 82^{*}$ & 0.42 & $0 \cdot 20,0 \cdot 89^{*}$ & $0 \cdot 61$ \\
\hline Bread & $0 \cdot 50$ & $0.28,0.89^{\star}$ & 0.49 & $0 \cdot 24,1 \cdot 01^{\star *}$ & 0.63 \\
\hline Pasta & 0.51 & $0.27,0.97^{\star}$ & 0.55 & $0.25,1.22$ & 0.59 \\
\hline Crackers & 0.25 & $0.08,0.73^{*}$ & $0 \cdot 24$ & $0.06,0.91^{*}$ & $0 \cdot 47$ \\
\hline \multicolumn{6}{|l|}{ Fruits } \\
\hline Fruit (all fruits, no juices) & $2 \cdot 79$ & $1.56,4.99^{*}$ & $2 \cdot 40$ & $1 \cdot 16,4 \cdot 97^{*}$ & 0.62 \\
\hline \multicolumn{6}{|l|}{ Vegetables } \\
\hline All dark green and yellow vegetables & $4 \cdot 82$ & $2 \cdot 61,8 \cdot 88^{*}$ & $4 \cdot 19$ & $1 \cdot 91,9 \cdot 21^{*}$ & $0 \cdot 86$ \\
\hline $\begin{array}{l}\text { Dark green and yellow vegetables (raw, cooked } \\
\text { or included in homemade recipes) }\end{array}$ & $4 \cdot 80$ & $2 \cdot 42,9 \cdot 54^{*}$ & $4 \cdot 05$ & $1 \cdot 68,9 \cdot 79^{\star}$ & 0.39 \\
\hline $\begin{array}{l}\text { Dark green and yellow vegetables (from fast-food } \\
\text { restaurants, processed or canned foods, etc.) }\end{array}$ & 0.50 & $0 \cdot 14,1 \cdot 82$ & $0 \cdot 60$ & $0 \cdot 12,3 \cdot 05$ & $0 \cdot 47$ \\
\hline $\begin{array}{l}\text { Other starchy vegetables (e.g. corn, immature } \\
\text { lima beans, lentil sprouts, peas, etc). }\end{array}$ & $1 \cdot 17$ & $0 \cdot 67,2 \cdot 05$ & $1 \cdot 51$ & $0.75,3.04$ & $0 \cdot 41$ \\
\hline \multicolumn{6}{|l|}{ Protein } \\
\hline Poultry & $1 \cdot 00$ & $0.57,1 \cdot 75$ & $0 \cdot 71$ & $0.35,1.44$ & 0.94 \\
\hline Beans & $1 \cdot 01$ & $0.55,1.86$ & $1 \cdot 46$ & $0.69,3.08$ & 0.57 \\
\hline Processed meat & $0 \cdot 26$ & $0 \cdot 14,0.49^{*}$ & 0.22 & $0.11,0.49^{*}$ & 0.06 \\
\hline \multicolumn{6}{|l|}{ Dairy } \\
\hline Sweetened milk beverage powder (e.g. cocoa) & $2 \cdot 27$ & $0 \cdot 97,5 \cdot 31^{\star \star}$ & $1 \cdot 34$ & $0 \cdot 47,3 \cdot 87$ & 0.61 \\
\hline Cheese & 0.25 & $0 \cdot 14,0 \cdot 45^{\star}$ & 0.27 & $0.13,0.56^{*}$ & 0.65 \\
\hline \multicolumn{6}{|l|}{ Beverages } \\
\hline Regular soft drinks & $0 \cdot 30$ & $0 \cdot 16,0 \cdot 57^{\star}$ & 0.25 & $0.11,0.55^{\star}$ & $0 \cdot 10$ \\
\hline Sweetened fruit drinks & 0.41 & $0.23,0.76^{\star}$ & 0.34 & $0 \cdot 16,0.72^{*}$ & 0.97 \\
\hline Beer and ale $\S$ & 0.00 & 0.00 & 0.00 & 0.00 & $0 \cdot 83$ \\
\hline \multicolumn{6}{|l|}{ Miscellaneous } \\
\hline Sugar & $2 \cdot 05$ & $1 \cdot 18,3 \cdot 58^{*}$ & $2 \cdot 15$ & $1 \cdot 07,4 \cdot 33^{*}$ & $0 \cdot 14$ \\
\hline Sweet baked goods & $0 \cdot 79$ & $0.41,1.50$ & 0.44 & $0 \cdot 20,0.98^{*}$ & $0 \cdot 82$ \\
\hline \multicolumn{6}{|c|}{ Odds of falling in the highest serving intake tertile } \\
\hline $\begin{array}{l}\text { Fruit and fruit juices (100\% citrus and non-citrus } \\
\text { fruit juice) }\end{array}$ & $1 \cdot 63$ & $0 \cdot 88,3 \cdot 04$ & $2 \cdot 17$ & $0 \cdot 97,4 \cdot 82^{\star *}$ & $0 \cdot 34$ \\
\hline All fruits (all combined, excluding fried fruit) & $1 \cdot 73$ & $0 \cdot 94,3 \cdot 22^{* *}$ & $2 \cdot 34$ & $1 \cdot 05,5 \cdot 23^{*}$ & $0 \cdot 44$ \\
\hline \multicolumn{6}{|l|}{ Vegetables } \\
\hline Tomatoes & $2 \cdot 07$ & $1 \cdot 13,3 \cdot 80^{*}$ & $2 \cdot 91$ & $1 \cdot 31,6 \cdot 47^{*}$ & 0.09 \\
\hline $\begin{array}{l}\text { Other non-starchy vegetables (e.g. beets, } \\
\text { cabbage, mung bean sprouts, summer } \\
\text { squash, etc.) }\end{array}$ & 3.00 & $1 \cdot 65,5 \cdot 45^{\star}$ & $3 \cdot 69$ & $1 \cdot 70,8 \cdot 04^{*}$ & 0.94 \\
\hline \multicolumn{6}{|l|}{ Protein } \\
\hline Meat (beef, lamb, veal, pork, organ meat) & 0.64 & $0 \cdot 32,1 \cdot 26$ & 0.93 & $0 \cdot 40,2 \cdot 15$ & 0.07 \\
\hline
\end{tabular}

${ }^{*} P \leq 0 \cdot 05 ;{ }^{* *} P \leq 0 \cdot 10$.

†Adjusted for education, marital status, enrolment in the Special Supplemental Nutrition Program for Women, Infants, and Children and in the Supplemental Nutrition Assistance Program, maternal age, pregnancy trimester at enrolment, number of people in the house.

$\ddagger$ The Hosmer-Lemeshow statistic was used to evaluate the fit of the multivariate logistic regression models.

§Consumed only by Puerto Ricans.

Abrams $(5 \cdot 8$ v. $2 \cdot 8$, respectively). Mean fruit serving intakes were higher in our sample compared with those reported by Guendelman and Abrams and by Harley et al. $(5 \cdot 0,1 \cdot 7$ and $2 \cdot 5-2 \cdot 8$, respectively) as were grain serving intakes $(7 \cdot 9,2 \cdot 6$ and $4 \cdot 1-4 \cdot 6$, respectively). Differences in nutrient and food group intakes between our study and others may be due to the following reasons: extremely small sample sizes of pregnant women in other stu$\operatorname{dies}^{(17,21)}$; different ways in which similar food groupings were defined ${ }^{(21)}$; different dietary intake methods $(24 \mathrm{~h}$ recall $v$. FFQ $)^{(16)}$; or differences in the recruited population characteristics (i.e. adult $v$. an adolescent sample) ${ }^{(22)}$. In addition, most of the previous studies were conducted over a decade ago.
Our study is unique because it examined intakes for over fifty nutrients and food groups to develop a comprehensive description of contemporaneous dietary intake patterns among pregnant Latina subgroups. The study published by Bowering et al. ${ }^{(18)}$ three decades ago was limited in scope as it reported intake differences for only nine nutrients. Both Bowering et al.'s study and ours found that a higher proportion of Puerto Rican Latinas consumed more energy and $\mathrm{Ca}$, whereas more nonPuerto Rican Latinas consumed higher levels of vitamin C. However, Bowering et al. found that a significantly higher proportion of Puerto Ricans had higher intakes of protein, whereas our study found no between-group differences in total protein intake. Thirty years later, we have 
expanded upon the study by Bowering et al., providing an extensive, complete, contemporary profile of nutrient and food group serving intakes and nutrient adequacy among low-income pregnant Latina subgroups living in the same geographical area.

The present study has several limitations. First, it documented and compared nutrient and food group intake patterns between Puerto Rican and non-Puerto Rican Latinas. Non-Puerto Rican Latinas came from Mexico, Central America, South America and the Caribbean. Unfortunately, our sample size was too small for expanding the number of ethnic subgroups modelled in the statistical analyses. Second, our study was not specifically designed to measure prenatal supplement use. Thus, we were unable to estimate their contribution towards overall nutrient intakes. Third, our results are only generalizable to those populations that have characteristics similar to those of the sample in the present study. Finally, results from our multivariate logistic regression analyses showed that the acculturation proxy variables and ethnicity were strongly related and consequently could not be entered together in the same model. These findings suggest that the associations between ethnicity and nutrient/food group intakes were mediated by acculturation proxies. This hypothesis needs to be confirmed through future longitudinal studies.

The documented differences in prenatal dietary intake based on Latina ethnicity that were found in the present study provide insights that may aid clinicians and dietitians working with these populations. If length of time spent in and acculturation to the USA erode the traditional, healthier eating patterns of Latinas, it is important that clinicians and dietitians focus on encouraging their less-acculturated Latina clients to retain their healthy cultural eating habits and educate those who are more acculturated about culturally appropriate healthy recipes and menus. Traditional eating patterns have been linked to more optimal birth weight ${ }^{(28)}$; therefore, educating clients on the benefits of traditional eating patterns may play an important role in facilitating an optimal birth outcome.

\section{Acknowledgements}

The present study was supported by the National Center on Minority Health and Health Disparities, NIH EXPORT Grant P20MD001765. The present study was also funded through the University of Connecticut Research Foundation, by the University of Connecticut USDA Food Stamp Nutrition Education Program and by a USDA National Needs pre-doctoral fellowship. The authors have no conflict of interest to declare. The content of this manuscript is solely the responsibility of the authors and does not necessarily represent the official views of the National Center on Minority Health and Health Disparities or of the National Institutes of Health. A.H.-F. and A.B.-M. designed and implemented the study, conducted the analyses and contributed to the writing of the full manuscript with A.H.-F. as lead author; S.S.-P. was project supervisor and contributed to the development of the final version of the manuscript; R.P.-E. was the principal investigator for the study and contributed to all aspects of the study and to writing of the manuscript. The authors thank Grace Damio and the staff from the Center for Community Nutrition and Comadrona Program at the Hispanic Health Council for their assistance in conducting the present study. The authors also thank the participants for their tremendous contribution by participating in the present study and Nishang Gupta for his assistance in helping to analyse the data.

\section{References}

1. Cobas JA, Balcazar H, Benin MB et al. (1996) Acculturation and low-birthweight infants among Latino women: a reanalysis of HHANES data with structural equation models. Am J Public Health 86, 394-396.

2. Moore VM, Davies MJ, Willson KJ et al. (2004) Dietary composition of pregnant women is related to size of the baby at birth. J Nutr 134, 1820-1826.

3. Cuco G, Arija V, Iranzo R et al. (2006) Association of maternal protein intake before conception and throughout pregnancy with birth weight. Acta Obstet Gynecol Scand 85, 413-421.

4. Mikkelsen TB, Osler M, Orozova-Bekkevold I et al. (2006) Association between fruit and vegetable consumption and birth weight: a prospective study among 43,585 Danish women. Scand J Public Health 34, 616-622.

5. Mannion CA, Gray-Donald K \& Koski KG (2006) Association of low intake of milk and vitamin D during pregnancy with decreased birth weight. CMAJ 174, 1273-1277.

6. Tamura T, Goldenberg RL, Johnston KE et al. (1997) Serum concentrations of zinc, folate, vitamins $\mathrm{A}$ and $\mathrm{E}$, and proteins, and their relationships to pregnancy outcome. Acta Obstet Gynecol Scand Suppl 165, 63-70.

7. Martinez de Villarreal LE, Delgado-Enciso I, Valdez-Leal R et al. (2001) Folate levels and N(5),N(10)-methylenetetrahydrofolate reductase genotype (MTHFR) in mothers of offspring with neural tube defects: a case-control study. Arch Med Res 32, 277-282.

8. Suarez L, Hendricks K, Felkner M et al. (2003) Maternal serum B12 levels and risk for neural tube defects in a Texas-Mexico border population. Ann Epidemiol 13, 81-88.

9. Kramer MS \& Kakuma R (2003) Energy and protein intake in pregnancy (review). Cochrane Database Syst Rev, issue 4, CD000032. http://onlinelibrary.wiley.com/o/cochrane/clsysrev/ articles/CD000032/pdf_fs.html

10. Lindblad B, Zaman S, Malik A et al. (2005) Folate, vitamin $\mathrm{B}_{12}$, and homocysteine levels in South Asian women with growth-retarded fetuses. Acta Obstet Gynecol Scand 84, 1055-1061.

11. Sabour H, Hossein-Nezhad A, Maghbooli Z et al. (2006) Relationship between pregnancy outcomes and maternal vitamin D and calcium intake: a cross-sectional study. Gynecol Endocrinol 22, 585-589.

12. Fuentes-Afflick E, Hessol NA \& Perez-Stable EJ (1999) Testing the epidemiologic paradox of low birth weight in Latinos. Arch Pediatr Adolesc Med 153, 147-153.

13. Rosenberg TJ, Raggio TP \& Chiasson MA (2005) A further examination of the 'epidemiologic paradox': birth outcomes among Latinas. J Natl Med Assoc 97, 550-556. 
14. Cohen BB, Friedman DJ, Mahan CM et al. (1993) Ethnicity, maternal risk, and birth weight among Hispanics in Massachusetts, 1987-89. Public Health Rep 108, 363-371.

15. March of Dimes (2005) Born too soon: prematurity in the US Hispanic population. http://www.marchofdimes. com/Peristats/pdfdocs/Hispanicptb05.pdf (accessed March 2011).

16. Harley K, Eskenazi B \& Block G (2005) The association of time in the US and diet during pregnancy in low-income women of Mexican descent. Paediatr Perinat Epidemiol 19, 125-134.

17. Abrams B \& Guendelman S (1995) Nutrient intake of Mexican-American and non-Hispanic white women by reproductive status: results of two national studies. $J \mathrm{Am}$ Diet Assoc 95, 916-918.

18. Bowering J, Lowenberg RL \& Morrison MA (1980) Nutritional studies of pregnant women in East Harlem. Am J Clin Nutr 33, 1987-1996.

19. Cohen GR, Curet LB, Levine RJ et al. (2001) Ethnicity, nutrition, and birth outcomes in nulliparous women. $A m \mathrm{~J}$ Obstet Gynecol 185, 660-667.

20. Gollenberg A, Pekow P, Markenson G et al. (2008) Dietary behaviors, physical activity, and cigarette smoking among pregnant Puerto Rican women. Am J Clin Nutr 87, 1844-1851.
21. Guendelman S \& Abrams B (1994) Dietary, alcohol, and tobacco intake among Mexican-American women of childbearing age: results from HANES data. Am J Health Promot $\mathbf{8}, 363-372$.

22. Gutierrez YM (1999) Cultural factors affecting diet and pregnancy outcome of Mexican American adolescents. J Adolesc Health 25, 227-237.

23. Suitor CW, Gardner JD \& Feldstein ML (1990) Characteristics of diet among a culturally diverse group of low-income pregnant women. J Am Diet Assoc 90, 543-549.

24. Harley K \& Eskenazi B (2006) Time in the United States, social support and health behaviors during pregnancy among women of Mexican descent. Soc Sci Med 62, 3048-3061.

25. Gibson R (1993) Nutritional Assessment. New York, NY: Oxford University Press.

26. Ayala GX, Baquero B \& Klinger S (2008) A systematic review of the relationship between acculturation and diet among Latinos in the United States: implications for future research. J Am Diet Assoc 108, 1330-1344.

27. Perez-Escamilla R \& Putnik P (2007) The role of acculturation in nutrition, lifestyle, and incidence of type 2 diabetes among Latinos. J Nutr 137, 860-870.

28. Wolff CB \& Wolff HK (1995) Maternal eating patterns and birth weight of Mexican American infants. Nutr Health 10, 121-134. 